\title{
Extraterritorial detention contracting in Australia and the UN Guiding Principles on Business and Human Rights
}

\author{
Brynn O'BRIEN*
}

Keywords: detention, immigration, refugees, Australia, contracting

\section{INTRODUCTION}

Australia stands alone in the world in its adoption of a system of mandatory, indefinite detention of asylum seekers entering its territory by boat. Asylum seekers from countries including Afghanistan, Iraq, Iran, Syria, Somalia, Vietnam, Myanmar and Sri Lanka have undertaken the boat journey from nearby transit countries in order to seek asylum in Australia. ${ }^{1}$ Australia is one of the few countries in the Asia-Pacific region to be both a signatory to the United Nations Convention Relating to the Status of Refugees (Refugee Convention) and adequately equipped for effective resettlement. For those who arrive by boat, the rates of acceptance of their Refugee Convention claims have been high. ${ }^{2}$

Under the Australian Migration Act 1958, people arriving by boat are detained as a matter of course $\mathrm{s}^{3}$ and for an unlimited period of time, with no prima facie rights of review of that detention in Australian courts. Boat arrivals are subject to removal to two extraterritorial detention centres (EDCs) ${ }^{4}$ - in Nauru, a small Pacific Island nation, and Manus Island, within the territory of Papua New Guinea - again, with no right of review

\footnotetext{
* Brynn O’Brien, BMedSci/LLB (UTS), LLM (Columbia), PhD candidate UTS; Business and Human Rights Technical Adviser, No Business in Abuse (NBIA). This paper is prepared in the author's personal capacity and does not necessarily reflect the views of NBIA. The author wishes to acknowledge the intellectual contribution of the entire NBIA collective, especially Shen Narayanasamy, Executive Director and Rachel Ball, International Advocacy lead, to this article.

1 For background, see Elibritt Karlsen, 'Refugee resettlement to Australia: what are the facts?' Australian Parliamentary Library, Laws and Bills Digest (3 February 2015), http://www.aph.gov.au/About_Parliament/Parliamentary_ Departments/Parliamentary_Library/pubs/rp/rp1415/RefugeeResettlement (accessed 12 February 2016).

2 After review, for applicants who have arrived by boat, rates of acceptance were 93.5 per cent of 2,909 applicants in 2010-11, and 91 per cent of 5,240 applicants in 2011-12. See Alex Reilly, 'FactCheck: are Australia's refugee acceptance rates high compared with other nations?', The Conversation (20 August 2013), http://theconversation.com/ factcheck-are-australias-refugee-acceptance-rates-high-compared-with-other-nations-17151 (accessed 11 February 2016).

3 Migration Act 1958 (Cth), secs 5AA and 189.

4 Ibid, sec 198AD.
} 
of the decision to remove them. ${ }^{5}$ This has meant that people seeking asylum, including children and infants (some of whom have been born in detention), have been detained in remote, inadequately serviced detention centres for years with no real possibility of challenging their detention in a court of law.

Australia's system of mandatory, indefinite detention has consistently been found by the UN Human Rights Committee to violate the prohibition on arbitrary detention, ${ }^{6}$ and has been widely condemned by credible local and international human rights authorities. ${ }^{7}$ Despite this condemnation, the policy has enjoyed long-term bipartisan support between Australia's two major political parties, and substantial public approval. These centres are run by companies to which Australia outsources its operational responsibility. Companies bid through competitive tender processes for lucrative contracts with the Australian Government.

In 2015, a collective of Australian lawyers, researchers and human rights activists formed No Business in Abuse (NBIA) as an independent, non-profit, non-government initiative to bring together a cross-section of Australian society to end the complicity of corporate entities in human rights abuses perpetrated within Australia's immigration system. This article discusses how NBIA has utilized the transnational business and human rights framework, specifically the UN Guiding Principles on Business and Human Rights (UN GPs) and the OECD Guidelines for Multinational Enterprises (OECD Guidelines), to ground its analysis and strengthen its advocacy against private sector involvement in extraterritorial detention.

\section{Detention Regime and Human Rights Abuses}

The system of mandatory, indefinite detention has been in operation in Australia under all successive governments since $1992 .{ }^{8}$ It has taken various forms, with the writing and rewriting of Australia's maritime boundaries and the opening, closing and reopening of detention camps in various locations in Australia and the Pacific. ${ }^{9}$

The Australian Government presently operates several detention facilities within its territory. ${ }^{10}$ These include facilities on the Australian mainland and on Christmas

\footnotetext{
5 Ibid, sec 198AD(4).

6 See decisions of UN Human Rights Council, $A$ v Australia (560/93), CCPR/C/59/D/560/93 (3 April 1997); C v Australia (900/99), CCPR/C/76/D/900/99 (13 November 2002); Baban v Australia (1014/01), CCPR/C/78/D/1014/ 2001 (18 September 2003); Shafiq v Australia (1324/04), CCPR/C88/D/1324/2004, (31 October 2006); Shams et al v Australia (1255, 1256, 1259, 1260, 1266, 1268, 1270 and 1288/04), CCPR/C/90/D/1255, 1256, 1259, 1260, 1266, 1268, 1270 and 1288 (11 September 2007); Bakhtiyari v Australia (1069/02) CCPR/C/79/D/1069/2002 (29 October 2003); D and Ev Australia (1050/02), CCPR/C/87/D/1050/2002 (9 August 2006).

7 Including the Australian Human Rights Commission, the UN High Commissioner for Human Rights, the UN QJ; High Commissioner for Refugees, the UN Special Rapporteur on the Human Rights of Migrants, the UN Special Rapporteur on Torture, Amnesty International, the Human Rights Law Centre (Melbourne, Australia), and Human Rights Watch.

8 For background, see Brynn O'Brien, 'Australia's founding father of indefinite, mandatory detention', $A B C$ online (11 November 2011), http://www.abc.net.au/news/2011-11-11/obrien-the-founding-father-of-australias-indefinitemandat/3658804 (accessed 11 February 2016).

9 See Angus Francis and Sonia Caton, 'Access to protection for "offshore entry persons", , Alternative Law Journal 36 (2011) 172 .

10 See Australian government, Department of Immigration and Border Protection, Immigration detention facilities, https://www.border.gov.au/Busi/Comp/Immigration-detention/facilities (accessed 11 February 2016).
} 
Island, an Australian territory in the Indian Ocean. Serco, a UK-headquartered multinational, is contracted by the Australian Government to operate the detention centres within Australia's territory. ${ }^{11}$ In September 2012 the system of 'offshore' detention of asylum seekers was re-established, with the EDCs re-opened in Nauru and Manus Island.

The evidence that mandatory, indefinite detention-at a systemic level-causes severe, and in some cases, irreparable, mental harm to people detained is overwhelming. ${ }^{12}$ Rates of self-harm-including self-harm by children-in Australia's immigration detention facilities are high. ${ }^{13}$ There have been numerous reports of physical abuse in detention. Two men have died as a result of their incarceration in the Manus Island centre since its reopening, ${ }^{14}$ while at the time this article was written, it appeared that no one had been resettled from the Manus EDC. As at January 2016, the average time of detention in each of the EDCs was in excess of 14 months. ${ }^{15}$

While the types of abuses that occur in both the onshore and extraterritorial detention contexts are similar, NBIA has prioritized an immediate focus on extraterritorial detention given the acuteness and severity of harms in the extraterritorial environment, as well as the secrecy surrounding them.

In November 2015, NBIA released a report (NBIA Report) documenting corporate complicity in Australia's systemic abuses, violating multiple treaties to which Australia is a signatory. ${ }^{16}$ These include arbitrary, indefinite detention and exposure to cruel, inhuman and degrading conditions. ${ }^{17}$ These abuses constitute violations of the International Bill of Rights, which, according to Principle 12 of the UN Guiding Principles on Business and Human Rights (UN GPs) are the relevant standards to be upheld by business enterprises.

11 Contract Notice, onshore detention services (9 January 2015), https://www.tenders.gov.au/?event=public. cn.view\&CNUUID=F166D1F4-FB57-E37B-3F635B399F4C3244 (accessed 11 February 2016).

12 For example, Professor David Isaacs, 'Are healthcare professionals working in Australia's immigration detention centres condoning torture?', Journal of Medical Ethics doi:10.1136/medethics-2015-103066, December 2015, http://jme. bmj.com/content/early/2015/12/20/medethics-2015-103066.short?g=w_jme_ahead_tab\&trendmd-shared=0 (accessed 11 February 2016); Elizabeth JM Corbett, Hasantha Gunasekera, Alanna Maycock and David Isaacs, 'Australia's treatment of refugee and asylum seeker children: the views of Australian paediatricians', Medical Journal of Australia (2014) 201 (7): 393-8, https://www.mja.com.au/journal/2014/201/7/australias-treatment-refugee-and-asylum-seekerchildren-views-australian (accessed 11 February 2016).

13 Michael Koziol and Nicole Hasham, 'Self-harm in detention centres at epidemic levels, internal documents show', The Sydney Morning Herald (16 January 2016), http://www.smh.com.au/federal-politics/political-news/selfharm-indetention-centres-at-epidemic-levels-internal-documents-show-20160115-gm74q3.html (accessed 11 February 2016).

14 Reza Berati died in February 2014 as a result of injuries sustained during unrest at the Manus EDC, see Kerry Brewster and Deb Richards, 'Manus Island riot: Asylum seeker speaks of witnessing Reza Berati's death', ABC Online (5 April 2014), http://www.abc.net.au/news/2014-04-04/manus-island-asylum-seekers-witness-statements-reza-beratideath/5367118 (accessed 11 February 2016); Hamid Kazei died after he contracted a bacterial infection and it took three days for the Iranian to be airlifted from Manus Island to hospitals in Port Moresby and finally Brisbane, see Jason Om, 'Hamid Khazaei: Rare bacterial infection killed Iranian asylum seeker detained on Manus Island' ABC Online (4 October 2014), http://www.abc.net.au/news/2014-10-04/iranian-asylum-seeker-died-of-rare-infection/5790364 (accessed 11 February 2016).

15 Stephanie Anderson, 'Immigration detention times on Nauru and Manus Island blow out to 450-day average under Liberals', ABC Online (13 January 2016), http://www.abc.net.au/news/2016-01-13/immigration-detention-timesblow-out-to-almost-450-days/7085264 (accessed 11 February 2016).

16 No Business in Abuse, Business in Abuse: Transfield's complicity in gross human rights abuses within Australia's offshore detention regime, (November 2015), https://www.nobusinessinabuse.org/site/about (NBIA Report).

17 Ibid, sections 6 and 7. 


\section{Corporations Involved in Extraterritorial Detention}

Australian Stock Exchange-listed company Broadspectrum Limited, formerly known as Transfield Services Limited, is presently contracted by the Australian Government to run the EDCs. The responsibilities of Broadspectrum include 'garrison support', maintenance and now, 'welfare' of people detained in the centres. The facilities are staffed by people employed by Broadspectrum or its subcontractors. Broadspectrum makes decisions about detainee welfare, movement, communication, behaviour, accommodation, food, clothing, water, security and general conditions. Broadspectrum can make recommendations as to whether the placement of detainees is appropriate, whether detainees are put into 'managed accommodation', and in certain circumstances to use force or authorize the use of force against detainees. ${ }^{18}$

The 18-month Broadspectrum contract to support the EDCs to October 2015 was valued at AU\$2.1 billion (US\$1.5 billion). This contract alone was estimated to constitute 'the vast majority' of the Broadspectrum Group's earnings in $2015 .{ }^{19}$ It was NBIA's analysis that Broadspectrum's listing on the ASX made it sensitive to reputational considerations, given the large holdings of its stock by a number of industry pension funds. According to Broadspectrum's 2015 annual report, the company intends to expand its operations with a new service line, 'Care and Welfare', and win more work in education, health, aged care and disability sectors. Any company seeking to win work in social and community-sectors is vulnerable to the impact of reputational harm.

Broadspectrum has had many opportunities to end its operational support for the EDCs. Yet, it has repeatedly signed new contracts without guaranteeing minimum human rights standards. Until 8 February 2016 it was the 'preferred tenderer' to sign a further five-year contract as the lead contractor to the EDCs. ${ }^{20}$ On 8 February 2016, the company announced a further one-year extension of its previous contract, and the government's intention to 'formally review and revise' the scope of the tender for extraterritorial work. ${ }^{21}$ This is a significant development, possibly demonstrating the impact of the public pressure applied to the extraterritorial detention regime, and hinting at its uncertain future.

Wilson Security, part of the British Virgin Islands-incorporated Wilson Group, subcontracts to Broadspectrum in the provision of security services at the EDCs. A number of other companies and non-government organizations contract on commercial terms to the Australian Government for EDC work. All organizations providing material support to Australia's extraterritorial detention regime, from those providing flights on which people are forcibly transferred, to performing construction and maintenance at the sites, to providing catering and services, could be considered 'contributing to' or

18 Transfield-DIBP contract 2014, Schedule 1, clause 4.16.

19 Ferrovial Bidder's Statement for Broadspectrum (7 December 2015), http://www.transfieldservices.com/news/ ferrovial-bidders-statement (accessed 11 February 2016).

20 Ben Doherty, 'Transfield named “preferred tenderer" for Manus and Nauru Centres', The Guardian Australia (31 August 2015), http://www.theguardian.com/world/2015/aug/31/transfield-named-coalitions-preferred-tenderer-formanus-and-nauru-centres (accessed 11 February 2016).

21 Broadspectrum announcement, 'DIBP extends Broadspectrum's contract for 12 months; Company further upgrades FY2016 guidance', Broadspectrum Website (8 February 2016), http://www.transfieldservices.com/news/ dibp-extends-broadspectrum-s-contract-for-12-months-company-further-upgrades-fy2016-guidance. 
'directly linked' to adverse human rights impacts, based on a UN GPs analysis. It is NBIA's view that no company should contract with the Australian Government's extraterritorial detention regime while minimum human rights standards cannot be guaranteed and are in fact routinely and systemically violated.

Spanish multinational Ferrovial launched a takeover bid for Broadspectrum on 4 December 2015. While Ferrovial has an explicit commitment to human rights due diligence, ${ }^{22}$ it is unclear whether its takeover processes took into account the NBIA Report. It is also unclear whether any of Ferrovial's due diligence appreciated the risk posed by a massive, Australia-wide community campaign. This bid was set to close on 22 February 2016, however, on 9 February 2016 Ferrovial announced its intention to reconsider its takeover bid after Broadspectrum's 'preferred tenderer' status for the fiveyear EDC contract was withdrawn. ${ }^{23}$

\section{UN GPS ANALYSIS}

In NBIA's assessment, Broadspectrum's involvement in operations at the EDCs is a textbook case of 'contribution to' adverse human rights impacts under UNGP 13(a), and an ongoing failure to discharge its responsibility to respect human rights in its business activities.

\section{A. State-sanctioned Abuse}

The human rights abuses inherent in Australia's extraterritorial detention regime are sanctioned and directed by the Australian Government, with the assistance of the governments of Nauru and PNG. This does not, however, excuse companies for their role in human rights abuses, ${ }^{24}$ nor does it absolve them of their ongoing responsibilities to respect human rights and to ensure that those who have been abused can access a remedy for those abuses. There can be little doubt that, without support from corporations, the operation of the EDCs - and the well-documented human rights abuses that go along with them, as outlined in the NBIA Report ${ }^{25}$ — would not be possible.

\section{B. Broadspectrum's Responsibility to Respect Human Rights}

Broadspectrum's responsibility under the UN GPs is to respect human rights in its business activities. ${ }^{26}$ This responsibility to respect human rights exists over and above

\footnotetext{
22 'Human Rights Policy - Ferrovial', Ferrovial website (18 December 2014), at page 3, https://www.google.com.au/ url?sa $=\mathrm{t} \& \mathrm{rct}=\mathrm{j} \& \mathrm{q}=\& \mathrm{esrc}=\mathrm{s} \&$ source $=$ web $\& \mathrm{~cd}=1 \& \mathrm{ved}=0$ ahUKEwiBgJ36e7KAhVjFqYKHQK5C-kQFggcMAA\&url $=$ http $\% 3 \mathrm{~A} \% 2 \mathrm{~F} \% 2 \mathrm{Fmemoria} 2014$.ferrovial.com\%2Frecursos\%2Fdoc\%2F2014\%2FArchivo\%2F46603_23223220151 43342.pdf\&usg=AFQjCNGqFQnzU2hqk3NYb0ObLJ-btL8GxQ\&sig2=WKqaNiQlEpNDfadJBWjZ4A (accessed 11 February 2016).

23 Ferrovial announcement, 'Extension of T/O offer' (9 February 2016), http://www.broadspectrum.com/investor/ ASX-announcements (accessed 11 February 2016).

24 Human Rights Council, 'Guiding Principles on Business and Human Rights: Implementing the United Nations "Protect, Respect and Remedy” Framework', A/HRC/17/31 (21 March 2011), Principle 11.

25 No Business in Abuse, Business in Abuse: Transfield's complicity in gross human rights abuses within Australia's offshore detention regime (November 2015), https://www.nobusinessinabuse.org/site/about (NBIA Report) at sections 6 and 7.

26 UN GPs, note 24, Principle 13(a).
} 
the requirement of compliance with the laws of PNG, Nauru or Australia, i.e., regardless of the purported 'domestic legality' of the company's actions. ${ }^{27}$

A company need not be the sole cause of an abuse to hold responsibility for it. ${ }^{28}$ In fact, the Interpretive Guide to the UN GPs, outlines a pertinent example of how a business could contribute to human rights abuses: 'performing construction and maintenance on a detention camp where inmates were allegedly subject to inhumane treatment'. ${ }^{29}$ Broadspectrum's provision of material support to the EDCs falls within the UN GPs' category of 'contributing to' an adverse human rights impact, at a minimum.

Broadspectrum itself has adopted the UN GPs. In its 2015 Human Rights Statement, the company states its commitment to 'International Human Rights Standards' ${ }^{30}$ Yet there is an obvious gulf between its in-principle commitments and its complicity in practice in a system of gross human rights violations.

Given the predictable nature of the abuses that have occurred, and the clear foreseeability of serious harm at the time of Broadspectrum's engagement with the extraterritorial detention regime, it seems implausible that any adequate due diligence (required under UN Guiding Principle 17) regarding the operation of an EDC would have failed to identify adverse human rights impacts.

\section{NBIA's Recommendations to Broadspectrum}

The UN GPs clearly require a company engaged in an 'adverse human rights impact' to end its contribution to the abuse. NBIA's recommendations to the company, therefore, as set out in the NBIA Report, are:

1. End its operations at the EDCs; and

2. Remedy the historical abuses in which it has been complicit.

Continuing to contract for EDC work with the full knowledge that it will be required to breach its responsibility to respect human rights in its business activities is, in NBIA's assessment, simply not a tenable position.

\section{Campaign Overview}

In September 2015 NBIA began a public campaign with the support of member-driven digital campaigning organization GetUp! to end business in abuse within Australia's detention centres. Over 40,000 people have now joined this campaign. The strength of the NBIA campaign has been in its provision of detailed and accurate information about

27 Ibid, Commentary to UN GP 11.

28 Ibid, Principle 13.

29 United Nations, 'The Corporate Responsibility to Respect Human Rights: An Interpretive Guide', $2012,17$.

30 Transfield Services Human Rights Statement, (June 2015), https://www.google.com.au/url?sa=t\&rct=j\&q= $\&$ esrc $=$ s\&source $=$ web $\& c d=1 \& c a d=$ rja\&uact $=8 \& v e d=0$ ahUKEwj5zvbAgu_KAhVGJ5QKHbKfAwMQFggeMAA \&url=http\%3A\%2F\%2Fwww.transfieldservices.com\%2Fpdf\%2FHuman_Rights_Statement_TMC-0000-LE-0020. pdf\&usg=AFQjCNFP5e72E9bqI9ZYpqMDQwiinQWiTA\&sig2=Jz4aKbVxN7N6JD6qUaTPpw $\quad($ accessed 11 February 2016). 
corporate involvement in immigration detention to the Australian private sector and the wider community.

The campaign has engaged with Broadspectrum's stakeholders-specifically the company's investors, financiers and client sectors-in order to raise awareness about the human rights abuses occurring at the EDCs, the role of contractors, and the risks posed to contractors' business partners through their association with a system of serious abuse. NBIA's analysis has been guided by the standards set by the UN GPs.

Entities that hold securities in, or have financial or business links with Broadspectrum, have been presented with an argument based on UN GP 13, demonstrating not only Broadspectrum's contribution to adverse human rights impacts but their own association with abuse through UN GP 13(b)'s extension of the responsibility to respect human rights through the value chain. NBIA's conversations with financial sector have involved both human rights and financial risk analyses. Several superannuation funds have publicly screened or divested from Broadspectrum on the basis the company's involvement in the detention regime. ${ }^{31}$

NBIA has started discussions with major private sector clients of Broadspectrum about the company's complicity in abuse. NBIA has also brought Broadspectrum's role in the detention system to the attention of a number of the company's public sector and community clients. The first coordinated 'community' effort to boycott future relationships with Broadspectrum has been in the local government sector in Australia. With GetUp!, NBIA developed a web portal through which residents of Local Government Areas (LGAs) around Australia can create and promote petitions to their local representatives asking them to reject business relationships with companies engaged in the immigration detention regime. ${ }^{32}$ To date, four LGAs have passed motions rejecting future dealings with companies engaged in offshore detention work, and a further 80 petitions to LGAs around Australia are active.

\section{SECRECY}

The operation of the EDCs is shrouded in secrecy. Under the Australian Border Force Act 2015 it is a criminal offence, punishable by two years' imprisonment, for anyone who does work (directly or indirectly) for the Australian Department of Immigration and Border Protection to disclose any information obtained by them while doing that work. ${ }^{33}$ The Act does not specify any exemptions in relation to the mandatory reporting of physical or mental harm, child abuse or any other such purpose in the public interest. In September 2015, the UN Special Rapporteur on the human rights of migrants cancelled a planned visit to Australia, due to the operation of this law. ${ }^{34}$ It is clear that its provisions

31 Joanna Mather, 'NGS Super dumps Transfield Services on "moral grounds"', The Australian Financial Review (25 August 2015), http://www.afr.com/news/ngs-super-dumps-transfield-services-on-moral-grounds-20150825-gj72tm (accessed 15 February 2016).

32 See No (local council) business in abuse, https://www.communityrun.org/efforts/no-business-in-abuse-localgovernment (accessed 11 February 2016).

33 Australian Border Force Act 2015, Act No. 40 of 2015, 2015, pt. 6. sec 4.

34 Statement of François Crépeau, 'Official visit to Australia postponed due to protection concerns', (25 September 2015), http://www.ohchr.org/EN/NewsEvents/Pages/DisplayNews.aspx?NewsID=16503\&LangID=E\#sthash.uNDcS0pw. dpuf. 
apply to Broadspectrum, and its employees, officers and directors, and any other parties providing services to the Manus and Nauru EDCs.

\section{Momentum is Building to End Business in Abuse}

Analysis of the extraterritorial detention system under the UN GPs has been a central and persuasive component of NBIA's engagement with the private sector. It has been effective in communicating the plural associations among Australian companies and the detention regime and in doing so, has given a new entry point to addressing a seemingly intractable system of abuse.

Broadspectrum looks increasingly isolated. Twelve months ago, it was a little-known logistics company preparing to tender for a lucrative five-year government contract. Now after pressure from its investors and financiers, with opposition to its activities building across its client sectors, and community outcry growing, its brand is indelibly associated with human rights abuse. It has accepted rolling, interim extensions of the contracts which enshrine its participation in the detention system, and is subject to a hostile takeover bid after devaluation of its shares.

Since NBIA's launch in 2015, Australia has seen a range of respected community members take action: doctors and nurses have protested against the policies; ${ }^{35}$ Clergy and religious orders have engaged in sit-ins ${ }^{36}$ and offered sanctuary to refugees facing deportation. ${ }^{37}$ Unions have rallied outside Broadspectrum offices, ${ }^{38}$ staff and students at the University of Newcastle have opposed the university's deal with Broadspectrum. ${ }^{39}$ Pension funds have divested shareholdings in Broadspectrum due to the company's association with abuse. ${ }^{40}$ In short, NBIA's corporate accountability activities are situated within a growing tide of opposition to mandatory, indefinite detention in Australia.

35 Helen Davidson, 'Hospital doctors protest to demand release of children from detention', The Guardian Australia (11 October 2011), http://www.theguardian.com/australia-news/2015/oct/11/hospital-doctors-protest-todemand-release-of-children-from-detention (accessed 11 February 2016).

36 Stephanie Anderson, 'Love Makes a Way: what drives these Christians to risk arrest?', SBS News online (21 May 2015), http://www.sbs.com.au/news/article/2015/05/21/love-makes-way-what-drives-these-christians-riskarrest (accessed 11 February 2016).

37 Marissa Calligeros, 'Anglican and Uniting churches offer sanctuary to asylum seekers after High Court ruling', The Age (4 February 2016), http://www.theage.com.au/victoria/melbourne-church-offers-sanctuary-to-asylum-seekersafter-high-court-ruling-20160203-gml603.html (accessed 11 February 2016).

38 Nick Toscano, 'Unions and Human Rights groups rally outside Transfield offices', The Age (25 September 2015), http://www.theage.com.au/victoria/unions-and-human-rights-groups-rally-against-detention-centre-operator-transfield20150925-gjuxh3.html (accessed 11 February 2016).

$39 \mathrm{ABC}$ online, 'Vice chancellor defends process around controversial contract', (15 December 2015), http://www. abc.net.au/news/2015-12-15/vice-chancellor-defends-process-around-controversial-contract/7029690.

40 Joanna Mather, 'NGS Super dumps Transfield Services on "moral grounds", The Australian Financial Review (25 August 2015). 